\title{
Vliv Halliwickova konceptu na rozvoj plaveckých dovedností u dětí s mozkovou obrnou a autismem
}

\section{The impact of the Halliwick concept to develop swimming skills in children with cerebral palsy and autism}

\author{
Tereza Vaščáková, Martin Kudláček
}

Fakulta tělesné kultury Univerzity Palackého v Olomouci

\begin{abstract}
Abstrakt
Přispěvek popisuje možnosti využití Halliwickova konceptu v rámci plaveckého výcviku a zhodnocení jeho vlivu pomocí WOTA testu. Plavání je pro klienty s diagnózou dètská mozková obrna (dále jen DMO) a autismem jednou z nejvhodnějšich pohybových aktivit. Pro klienty se specifickými nároky je však zapotřebí nejen změna činností, ale celého přistupu instruktorů. Jednou z forem, které plně respektují tyto požadavky, je Halliwickův koncept plavecké výuky. Motorická kompetence je jedním z významných ukazatelì vývoje osobnosti, má i sociální rozměr. V termínu motorická kompetence se sumuje kontinuum: analýza a deskripce stavu - přijetí opatřeni k modifikacim a zlepšení stavu (Válková, 2010) K hodnocení výsledkủ jsem využila Test plaveckých dovedností (dále jen WOTA - Water orientation test (Tirosh, Katz-Leurer \& Getz, 2008). Předkládané výsledky predstavuji pilotní studii. Studie byla prováděna na 15 probandech s různými typy DMO a autismem. Studie měla pretest a posttest design s dvouměsičním intenzivním tréninkem plaváni pomoci Halliwickova konceptu. Jelikož jsem nepracovala s homogenni skupinou klienti̊, probandi byli rozděleni do tři skupin dle typu diagnózy (kvadruspastická forma DMO, diparetická forma DMO a autismus). Po dvouměsičním kurzu jsem hodnotila změny plaveckých dovedností pomocí WOTA testu.
\end{abstract}

\begin{abstract}
Stoking post describes how to use Halliwick concept in swimming training. Swimming is for clients diagnosed with cerebral palsy (CP) and autism, one of the best physical activities. For clients with special needs but requires only changing the activity but the approach instructors. One of the ways that fully respect these requirements is Halliwick concept of swimming lessons. Motor competence is one of the important indicators of personality development, has a social dimension. The term motor skills with noise continuum: analysis and description of the state - the adoption of measures to modification and improvement (Válková, 2010) to evaluate the results of the use of the test swimming skills (hereinafter WOTA - Water orientation test (Tirosh, Katz-Leurer \& Getz, 2008). The present results represent a pilot study. Study was conducted in 15 probands with different types of cerebral palsy and autism. Study had pretest and posttest design with a two-month intensive training session with swimming Halliwick concept. Since we have worked with a homogeneous group of clients probands were divided into three groups according to the type of diagnosis (quadruparetic form of cerebral palsy, diparetic form of cerebral palsy and autism) and after a two-month course we evaluated the changes of swimming skills through WOTA test.
\end{abstract}

Klíčová slova: Motorická kompetence, Halliwickův koncept, dětská mozková obrna, autismus, plavecký výcvik, plavecké dovednosti, WOTA.

Key words: Motor skills, Halliwick concept, cerebral palsy, autism, swimming training, swimming skills, WOTA. 


\section{ÚVOD}

Př́spěvek popisuje možnosti využití Halliwickova konceptu v rámci plaveckého výcviku. Plavání je pro klienty s diagnózou dětská mozková obrna (dále jen DMO), a nejen pro ně, jednou z nejvhodnějších pohybových aktivit. Pro děti se specifickými nároky je však zapotřebí nejen změna činností, ale celého př́stupu instruktorů. Jednou z forem, které plně respektují tyto požadavky, je Halliwickův koncept plavecké výuky (Kepštová, 2011).

Je to metoda plavání zejména pro handicapované děti, ale velmi dobře se uplatňuje i u dětí trpících anxiózními pocity z vodního prostředí (Pacholík, Vlčková \& Blahutková, 2009).

Úspěch při překonávání těchto pocitů posiluje především sebedůvěru ve vlastní síly a odvahu (Šarinová, Čechovská, 2005).

Halliwickův koncept (dále jen HK) je forma aktivní vodní terapie, která využívá jedinečných vlastností vodního prostředí (tlak, vztlak, nestálost prostředí), přičemž dodržuje základní principy HK (Halliwick AST, 1992).

Popisují se tři základní principy HK - princip individuálního přístupu, osobního kontaktu a soběstačnosti. To znamená, že každý klient má po celou dobu terapie svého osobního asistenta, který s ním vizuálně, verbálně, ale zejména manuálně komunikuje a může aktivně reagovat na změny motorické aktivity klienta. Obrovskou výhodou tohoto př́stupu je, že klienti jsou hodnoceni individuálně, klient s asistentem pracuje dle svého tempa a dle svých možností. Během terapií se také nevyužívají žádné podpůrné pomůcky typu plaveckých kruhů či plaveckých rukávků, které fyziologický pohyb ve vodě spíše znesnadňují (Saulová, 2007).

Využívají se pouze různé motivační prvky, jako jsou „plovací vajíčka“, které mají klienti sbírat a aktivovat úchop, či „plovací barevné tyčinky“, které se využívají při motivaci k rotacím těla klienti̊, či naopak ,zářivé tyčinky“, které se potápí a klienti jsou motivováni ke sběru těchto tyčinek, a tím k ponoření obličeje a hlavy, a tím také ke kontrole dechu.

Páteří této metody je „Desetibodový program“, který vyplývá z logických, po sobě jdoucích kroků, které se navzájem prrekrývají. Program začíná psychickou adaptací klienta na vodní prostředí, nacvičuje transfery z vozíku na okraj bazénu a poté do bazénu, vyučuje rotacím těla ve vodním prostředí (vertikální, sagitální, kombinované rotace), splývání těla až po základní plavecké pohyby ve vodním prostředí.

Abychom mohli reálně zhodnotit změny plaveckých dovedností klientů a tedy jejich motorickou kompetenci ve vodním prostředí, vybrali jsme k tomu hodnotící škálu WOTA.

Harris \& Dendy (1992) udávají, že velmi vhodnou metodou rehabilitace dětí s DMO je Halliwickův koncept plavání. Plavání je pro děti s diagnózou DMO jednou z nejvhodnějších pohybových aktivit. Specifické vlastnosti vodního prostředí usnadňují a umožňují dětem s poruchou hybnosti samostatnou bipedální lokomoci, která je za normálních podmínek možná pouze s využitím kompenzačních pomůcek. Plávání a speciální Halliwickův koncept je i velmi dostupnou aplikovanou pohybovou aktivitou pro tyto děti.

Taktéž Pacholík (2010) velmi vyzdvihuje léčebné účinky a pozitivní působení nejen vodního prostředí, ale zejména systematického působení na děti s handicapem. Uvádí, že právě Halliwickův koncept plavání je velmi vhodným nástrojem pro toto působení a ovlivňuje motorické kompetence.

Getz, Hutzler \& Vermeer (2006) systematicky vyhodnotili literaturu o výzkumech vodní intervence na populaci. Provedli selekci ze 173 článků, které vyhledali na databázích MEDLINE, PubMed, ERIC, PsychLit, PEDro, Sport Discus, CINAHL, Cochrane od roku 1966 až po 2005. Po selekci vybrali 11 článků, které se úzce zabývají efekty vodní intervence na děti s dětskou mozkovou obrnou. Z těchto jedenácti článků sedm článků poukazuje, že tyto plavecké intervence mají pozitivní vliv na zdokonalení motorických funkcí člověka, dva udávají pozitivní změny na člověka a dva články udávají, že nezaznamenaly žádné změny po vodní terapii. Žádný článek neudává, že by byly zaznamenány negativní účinky vodní intervence.

Getz a kol. (2006) v článku ,The relationship between aquatic indepedendce and Gross motor function in children with neuro-motor impairments“ popisuje výzkum, který byl proveden na vzorku 49 dětí s DMO, kde byl použit pro kontrolu úspěšnosti Halliwickova konceptu plavání test Gross motor function measure (dále jen GMFM). V diskuzi popisuje signifikantní zlepšení GMFM po aplikaci Halliwickova konceptu plavání.

Tirosh a kol. (2008) se také podrobně zabývá Halliwickovým konceptem a přináší novou hodnotící škálu plavecké terapie, která vychází z uvedené terapie. V článku se zaměřuje na přesné rozdělení desetibodového programu Halliwickova konceptu a vytvoření vnitřní hodnotící škály, tzv. WOTA (The water orientation test of Alyn). Tuto novou metodu jsem hodnotila na vzorku 32 handicapovaných plavců. Výsledkem studie je, že tento test je proveditelný a použitelný jako nástroj pro zhodnocení rozvoje plaveckých dovedností handicapovaných plavců. 
Grosse (2010) popisuje tři kazuistiky pacientů. Tito pacienti byli handicapovaní tím, že klasický př́stup k výuce plavání je pro ně nepřijatelný. Proto jejich lektorka hledala jiný, alternativní způsob nejen výuky plavání, ale celý př́stup k výuce plavání, a tím i k rozvoji jejich motorické schopnosti. Uvádí, že právě Halliwickův koncept plavání může přinést benefity různě handicapovaným lidem, nejen pro děti s DMO, ale i pro obézní pacienty a pacienty, kteří trpí extrémní úzkostí z vody. Jednou z kazuistiky je příběh Sally, která má DMO a která díky Halliwickově konceptu získala schopnost využít nové aplikované pohybové aktivity. Předtím, než začala využívat Halliwickova konceptu, dívka nikdy neplavala, a tudíž netušila, jaké pohybové schopnosti se v ní skrývají. Poté co začala aktivně plavat pomocí Halliwickova konceptu, rozvinula se její motorická schopnost natolik, že byla schopna i individuálního potápění. Tím její život dostal další rozměr - podvodní.

Cílem příspěvku je zjistit vliv Halliwickova konceptu na nácvik plaveckých dovedností u dětí s DMO a autismem.

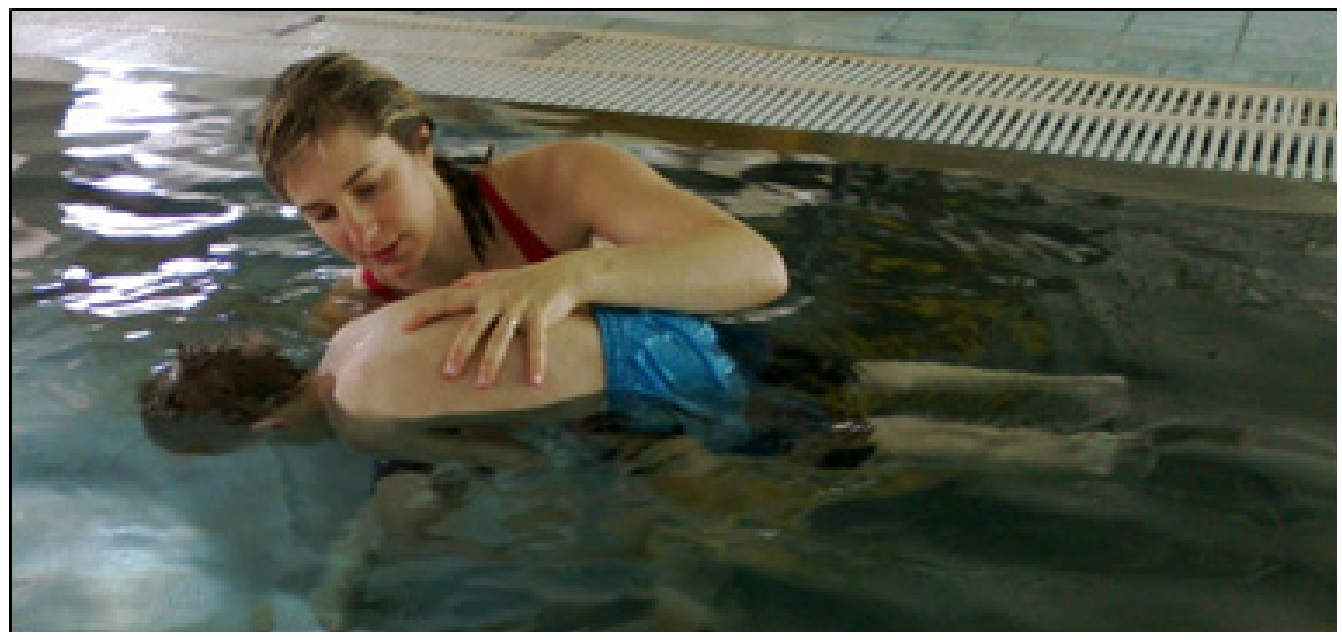

Obr. 1: Nácvik potápění dle Halliwickova konceptu

\section{METODIKA}

$\mathrm{Na} 15$ probandech s různými typy diagnóz DMO a autismu byl prováděn dvouměsíční intenzivní kurz Halliwickova konceptu plavání. Klienti pravidelně navštěvují denní stacionář při Jitro, o.p.s. Olomouc. Tento denní stacionáŕ ve spolupráci s FTK UP Olomouc provozuje pravidelné plavecké tréningy pod vedením fyzioterapeutky a instruktorky Halliwickova konceptu. Jelikož jsme pracovali s heterogenní skupinou probandů s velmi rozlišnými klinickými obrazy diagnózy DMO a autismu, bylo by hodnocení pokroku všech klientů dohromady velmi zkreslené. Proto jsme výsledky hodnocení rozdělili do tří skupin (diparetická forma DMO - 4 probandi ve věku 8-14 let, kvadruparetická forma DMO - 6 probandů ve věku 8-15 let, autismus - 5 probandů ve věku $7-10$ let). 


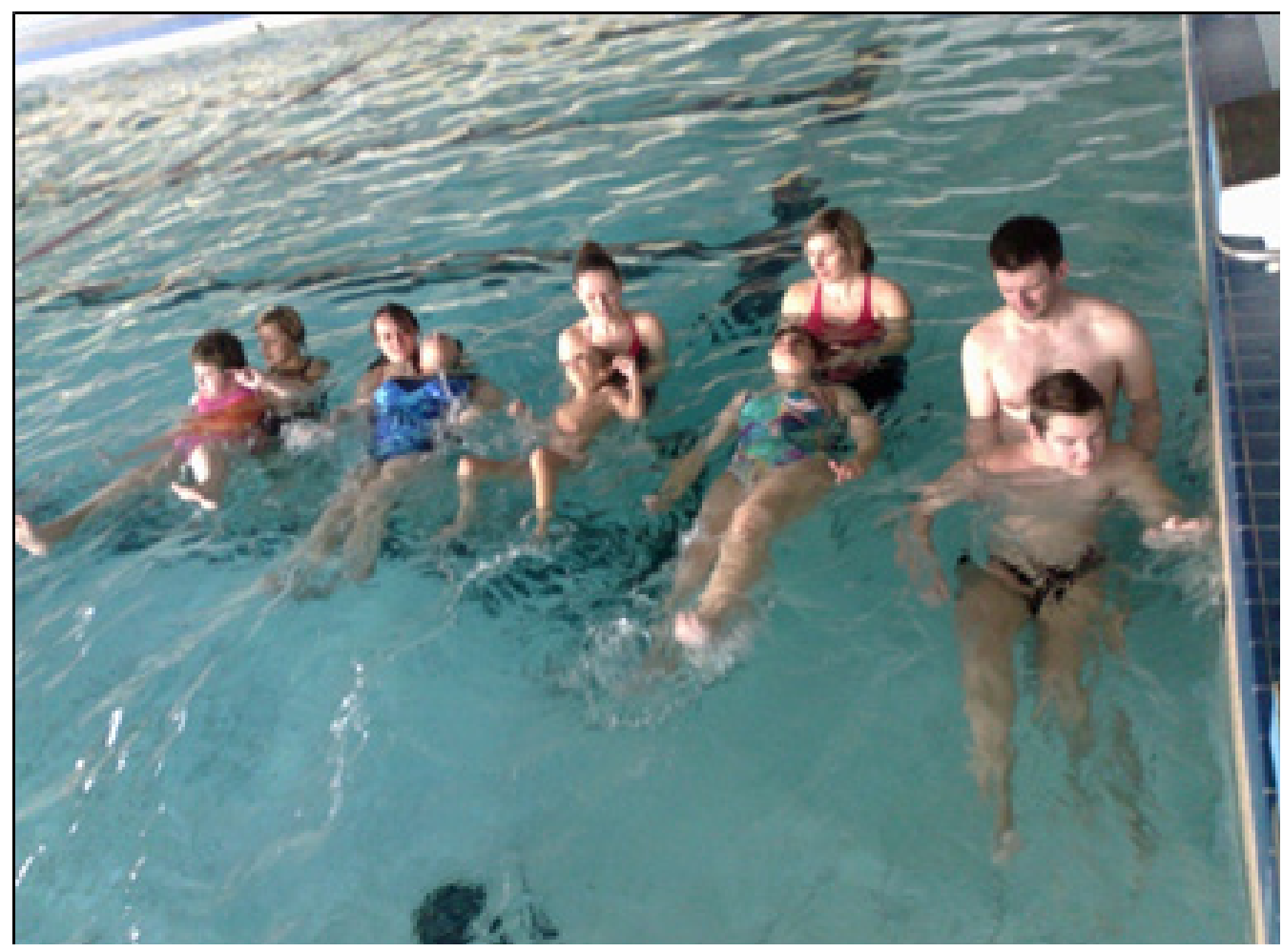

Obr. 2: Nácvik základních plaveckých pohybů

Před a po zahájení Halliwickova konceptu jsem provedla test plaveckých dovedností - WOTA (Water orientation test; Tirosh, Katz-Leurer \& Getz, 2008) - pretest a postest design výzkumu. Tento test obsahuje 13 podtestů, proband je skórován dle škály od 1 do 4 bodů dle kvality provedení plaveckých dovedností. V hodnocení je přesně uvedeno, jak tento pohyb má vypadat včetně pohybů rukou, nohou i hlavy (viz přikládaný test WOTA). Nejvíce tedy proband může dosáhnout 52 bodů. Vyhodnotila jsem tyto testy po dvouměsíční terapii, zda došlo ke zlepšení/zhoršení plaveckých dovedností probandů. Jedna terapie trvala 45 minut čistého času, 1x týdně. Celkem bylo provedeno 10 terapií. Testy vyhodnocovala vždy stejná osoba (autorka článku) ve stejném prostředí ve stejnou denní dobu.

\begin{tabular}{|c|c|c|}
\hline \multicolumn{2}{|c|}{ Orientační test plaveckých dovedností } \\
\hline \multirow{4}{*}{$\begin{array}{c}\text { 1. Akceptace } \\
\text { vodního prostředí }\end{array}$} & vstoupí do bazénu ochotně & 4 \\
\cline { 2 - 3 } & lehce pochybuje, indiferentní & 3 \\
\cline { 2 - 3 } & má obavy, lpí na instruktorovi & 2 \\
\cline { 2 - 3 } & odmítavý, uslzený & 1 \\
\hline \multirow{2}{*}{$\begin{array}{c}\text { 2. Vstup do } \\
\text { bazénu } \\
\text { (vertikální) }\end{array}$} & samostatně, skočí šipku & 4 \\
\cline { 2 - 3 } & jen s dopomocí, podpora rukou & 3 \\
\cline { 2 - 3 } & s dopomocí , podpora předloktí & 2 \\
\hline \multirow{3}{*}{$\begin{array}{c}\text { 3. Výstup z } \\
\text { bazénu }\end{array}$} & s dopomocí, podpora trupu & 1 \\
\cline { 2 - 3 } & doplave k okraji, sám nevyleze & 3 \\
\cline { 2 - 3 } & s dopomocí, usedí na okraji & 2 \\
\cline { 2 - 3 } & plně s dopomocí bez iniciativity & 1 \\
\hline
\end{tabular}




\begin{tabular}{|c|c|c|}
\hline \multirow{4}{*}{$\begin{array}{l}\text { 4. Dechová } \\
\text { kontrola }\end{array}$} & fouká bubliny nosem i pusou & 4 \\
\hline & Fouká bubliny jen ústy & 3 \\
\hline & ponoří ústa, bez foukání & 2 \\
\hline & polyká vodu, bez iniciativity & 1 \\
\hline \multirow{4}{*}{$\begin{array}{l}\text { 5. Horizontální } \\
\text { rotace }\end{array}$} & splývá, vrátí se zpět na záda & 4 \\
\hline & splývá, nevrátí se na záda & 3 \\
\hline & splývá na boku, není relaxován & 2 \\
\hline & křečovitý, odmítavý & 1 \\
\hline \multirow{4}{*}{$\begin{array}{l}\text { 6. Splývání na } \\
\text { zádech }\end{array}$} & relaxován, vrátí se do vertikály & 4 \\
\hline & relaxován, ne do vertikály & 3 \\
\hline & relaxuje, zvedá se & 2 \\
\hline & odmítavý, bojácný & 1 \\
\hline \multirow{4}{*}{$\begin{array}{l}\text { 7. Stř́ikání vody } \\
\text { kolem sebe }\end{array}$} & zvládá HKK i DKK, necouvá & 4 \\
\hline & opatrně stř́ká, ne na obličej & 3 \\
\hline & nestř́íká vodu, ale nebojí se & 2 \\
\hline & bojí se, pasivní & 1 \\
\hline \multirow{4}{*}{$\begin{array}{l}\text { 8. Potápění se, } \\
\text { ponoření se }\end{array}$} & vyloví předmět pod vodou & 4 \\
\hline & ponořuje hlavu & 3 \\
\hline & neinicuje ponor & 2 \\
\hline & KI ponoření hlavy & 1 \\
\hline \multirow{4}{*}{$\begin{array}{c}\text { 9. Schopnost } \\
\text { udržet se ve } \\
\text { vertikální poloze }\end{array}$} & s podporou dlaní & 4 \\
\hline & s podporou předloktí & 3 \\
\hline & s podporou HKK, ramen, trupu & 2 \\
\hline & bojí se, neproveditelné & 1 \\
\hline \multirow{4}{*}{$\begin{array}{l}\text { 10. Kvadrupedální } \\
\text { lokomoce ve vodě } \\
\text { (vertikální) }\end{array}$} & samostatně & 4 \\
\hline & u stěny samostatný & 3 \\
\hline & podpora u stoje i úkrocích & 2 \\
\hline & nezvládá, bojí se & 1 \\
\hline \multirow{4}{*}{$\begin{array}{l}\text { 11. Stoj ve vodě, } \\
\text { voda v úrovni } \\
\text { hrudníku }\end{array}$} & sám, dlouhodobě & 4 \\
\hline & vydrží 10 s, poté padá & 3 \\
\hline & stoj jen s podporou & 2 \\
\hline & stoj není možný & 1 \\
\hline \multirow{4}{*}{$\begin{array}{l}\text { 12. Držení se lana, } \\
\text { hrudník nad } \\
\text { vodou }\end{array}$} & postupuje, střídá ruce & 4 \\
\hline & udrží se $10 \mathrm{~s}$ & 3 \\
\hline & udrží se s oporou & 2 \\
\hline & neudrží se & 1 \\
\hline \multirow{4}{*}{$\begin{array}{l}\text { 13. Sed ve vodě, } \\
\text { pozice židle, } \\
\text { brada ve vodě, } \\
10 \mathrm{~s}\end{array}$} & lehká podpora pánve & 4 \\
\hline & lehká podpora kolem pasu & 3 \\
\hline & podpora kolem trupu & 2 \\
\hline & křečovitý, nelze provést & 1 \\
\hline \multicolumn{3}{|l|}{ Jméno: } \\
\hline \multicolumn{3}{|l|}{ Diagnóza: } \\
\hline \multicolumn{3}{|l|}{ Datum narození: } \\
\hline \multicolumn{3}{|l|}{ Jméno instruktora: } \\
\hline Datum: & & \\
\hline
\end{tabular}




\section{VÝSLEDKY}

Graf a tabulka 1: Výsledky pro klienty s diparetickou formou DMO

\begin{tabular}{|c|c|c|c|c|c|c|c|c|c|c|c|c|c|}
\hline & $\begin{array}{l}\text { Akceptac } \\
\text { e vodního } \\
\text { prostředí }\end{array}$ & $\begin{array}{l}\text { Vstup do } \\
\text { bazénu }\end{array}$ & $\begin{array}{l}\text { Výstup z } \\
\text { bazénu }\end{array}$ & $\begin{array}{l}\text { Dechová } \\
\text { kontrola }\end{array}$ & $\begin{array}{l}\text { Horizontá } \\
\text { Iní rotace }\end{array}$ & Splývání & $\begin{array}{l}\text { Strǐkání } \\
\text { vody }\end{array}$ & $\begin{array}{l}\text { Potápění } \\
\text { se/ponoř } \\
\text { ení se }\end{array}$ & $\begin{array}{l}\text { Udržení } \\
\text { ve } \\
\text { vertikální } \\
\text { poloze }\end{array}$ & $\begin{array}{c}\text { Kvadrupe } \\
\text { dální } \\
\text { lokomoce }\end{array}$ & $\begin{array}{l}\text { Stoj ve } \\
\text { vodĕ }\end{array}$ & $\begin{array}{c}\text { Držení se } \\
\text { lana }\end{array}$ & $\begin{array}{c}\text { Sed ve } \\
\text { vodě, } \\
\text { pozice } \\
\text { židle }\end{array}$ \\
\hline $\begin{array}{c}\text { před } \\
\text { terapií } \\
\text { Halliwick } \\
\text { metodou }\end{array}$ & 3,5 & 2,2 & 2,3 & 2,3 & 2,2 & 2,8 & 3,0 & 2,0 & 2,3 & 2,3 & 2,3 & 2,3 & 2,3 \\
\hline $\begin{array}{l}\text { po terapií } \\
\text { Halliwick } \\
\text { metodou }\end{array}$ & 3,8 & 3,2 & 3,2 & 3,5 & 4,0 & 4,0 & 3,7 & 3,3 & 3,7 & 3,8 & 3,5 & 4,0 & 3,8 \\
\hline
\end{tabular}

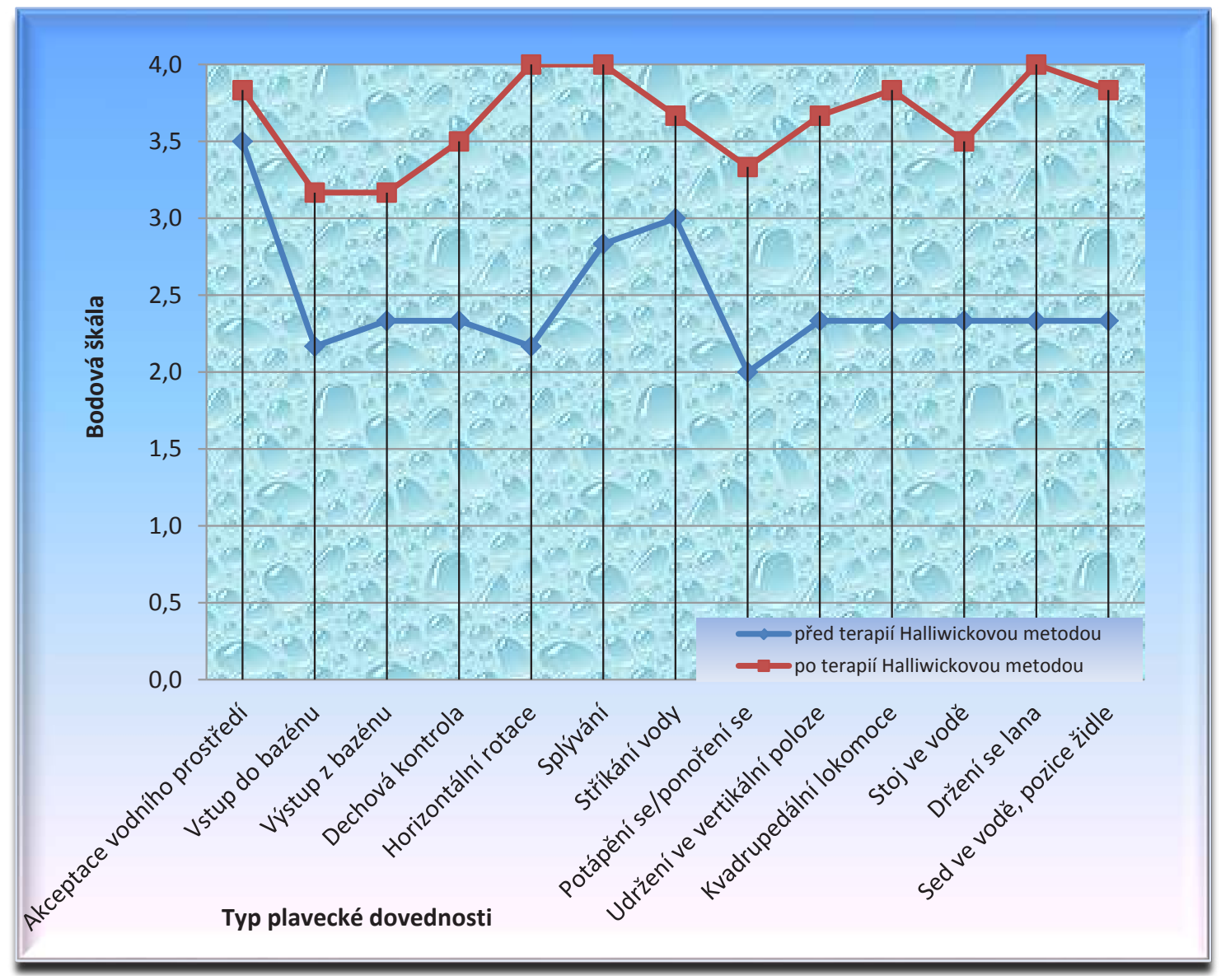

Nejlepší výsledky v plaveckých dovednostech prokázali klienti s diparetickou formou DMO, kteří dosáhli v průměru zlepšení o 1,2 bodu z hodnotící škály - viz tabulka a graf č. 1 . Počet probandů $n=4$.

Rozdíl je zřetelný v hodnocení výsledků v nácviku transferů klientů do a z vody, což je velmi důležitou součástí plavecké výuky a akceptace vodního prostředí - nebojí se vody, ochotně a rádi vstupují do vodního prostředí a na tuto aktivitu se těší. Překonali svou omezenou možnost př́stupu do bazénu a osvojili si nové pohybové transfery, které pak mohou využít i při běžném životě (ADL - activity of daily living).

Jako pokrok také vidím rozdíl $\mathrm{v}$ hodnocení dechové kontroly. Vysvětlit a poté také naučit tyto klienty aktivně kontrolovat dech ve vodním prostředí považuji za jednu z nejtěžších aktivit. Rozbourat mnohdy zakořeněný stereotyp dýchání pouze ústy je velmi těžké. A zakomponovat pravidelný nádech nosem a výdech ústy do vody při pohybové aktivitě je koordinačně velmináročné. Klienti mají často pocit dechové nedostatečnosti, polykají vodu a cítí v tomto dechovém stereotypu diskomfort. Proto považuji za úspěch, že jsme naučili (spolu s asistenty klientů) správnému stereotypu dýchání ve vodním prostředí alespoň některé $\mathrm{z}$ nich. 
Nácvik horizontální rotace ve vodním prostředí představoval problém, spíše se jevil problém nacvičit splývání na hladině vody. Tato aktivita by se měla učit jako první, aby klienti měli pocit bezpečí ve vodě, cítit, že při správném splývání je voda nadnáší a oni mohou ve vodním prostředí i relaxovat.

Dalším problémem byl nácvik potápění, což úzce souvisí s dechovou kontrolou, kterou jsem popsala. Deset z patnácti klientů zvládlo nácvik ponoření hlavy pod hladinu, ale již bylo pro ně velkým problémem se pod hladinou orientovat a pohybovat se pod ní. Proto je také tato aktivita rozdělena do dvou částí - ponoření a potápění, př́ípadně pohyb pod hladinou, např. vylovení pomůcky.

Nácvik vertikální polohy ve vodě a následně nácvik samostatného stoje a kvadrupedální lokomoce v horizontále je pro klienty s DMO a s omezenou bipedální lokomocí na souši velice obohacující. Perfektně se trénuje fyziologický program nácviku chůze, proprioceptivní stimulace z plosek nohou, objevují nový nezávislý pohyb.

Graf a tabulka 2: Výsledky pro klienty s autismem

\begin{tabular}{|c|c|c|c|c|c|c|c|c|c|c|c|c|c|}
\hline & $\begin{array}{l}\text { Akceptace } \\
\text { vodního } \\
\text { prostředí }\end{array}$ & $\begin{array}{l}\text { Vstup do } \\
\text { bazénu }\end{array}$ & $\begin{array}{l}\text { Výstup z } \\
\text { bazénu }\end{array}$ & $\begin{array}{l}\text { Dechová } \\
\text { kontrola }\end{array}$ & $\begin{array}{l}\text { Horizontá } \\
\text { Iní rotace }\end{array}$ & Splývání & $\begin{array}{l}\text { Stř́ikání } \\
\text { vody }\end{array}$ & $\begin{array}{l}\text { Potápění } \\
\text { se/ponoř } \\
\text { ení se }\end{array}$ & $\begin{array}{l}\text { Udržení } \\
\text { ve } \\
\text { vertikální } \\
\text { poloze }\end{array}$ & $\begin{array}{c}\text { Kvadrupe } \\
\text { dální } \\
\text { lokomoce }\end{array}$ & $\begin{array}{l}\text { Stoj ve } \\
\text { vodě }\end{array}$ & $\begin{array}{c}\text { Držení se } \\
\text { lana }\end{array}$ & $\begin{array}{c}\text { Sed ve } \\
\text { vodě, } \\
\text { pozice } \\
\text { židle } \\
\end{array}$ \\
\hline $\begin{array}{c}\text { před } \\
\text { terapií } \\
\text { Halliwick } \\
\text { metodou }\end{array}$ & 4 & 3,6 & 4 & 2,6 & 2,4 & 3,6 & 4 & 1,8 & 3,2 & 3,6 & 4 & 2,4 & 3,8 \\
\hline $\begin{array}{l}\text { po terapií } \\
\text { Halliwic } \\
\text { metodou }\end{array}$ & 4 & 3,6 & 4 & 3,8 & 4 & 4 & 4 & 3,6 & 3,8 & 4 & 4 & 4 & 4 \\
\hline
\end{tabular}

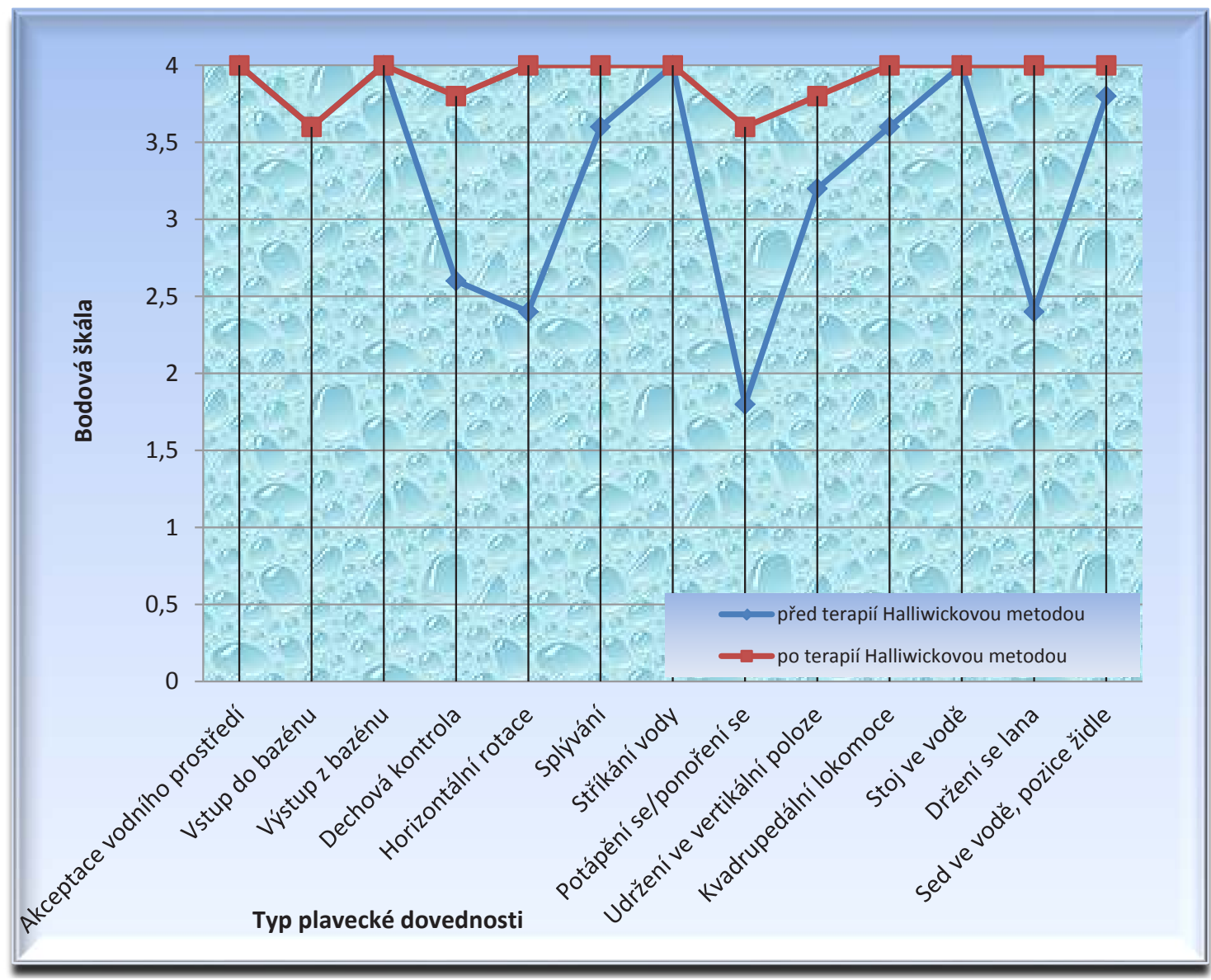


Druhá skupina, klienti s autismem, prokázali zlepšení v bodovém hodnocení o 0,6 bodu - viz tabulka a graf č. 2. Počet probandů $n=5$.

Tito klienti neměli velké problémy s motorickou kompetencí ve vodě, proto nebyly markantní rozdíly $\mathrm{v}$ jejich plaveckých a vodních dovednostech jako u předchozí skupiny. Velký problém je u nich vypěstovat nový návyk, který bude pro ně stabilní, budou se v něm cítit dobře a bezpečně a budou při něm spolupracovat. Proto jsme kladli (spolu s asistenty klientů) velký důraz na první položku a trénovali jsme zpočátku zejména adaptaci klienta na vodní prostředí, k čemuž patř́i také transfery a stř́ikání vody kolem sebe. Stav, kdy přijali vodní prostředí a cítí se v něm dobře.

Neměli jsme velké úspěchy při nácviku splývání a nácviku statických poloh a relaxací ve vodě, což také vyplývá z charakteru diagnózy těchto klientů. Preferují spíše aktivní, opakující se činnosti.

Měli jsme však úspěch v nácviku dechové kontroly a ponoření se a potápění se pro daný předmět. Nácvik této aktivity přijímali pozitivně, měli silnou motivaci - vylovený předmět.

Nácvik stoje, kvadrupedální lokomoce $\mathrm{v}$ horizontále, nebyl pro tyto klienty velkým problémem, jelikož všichni zvládali samostatnou bipedální lokomoci. Proto jsme si mohli dovolit s těmito klienty i nácvik samostatných plaveckých způsobů, jelikož se cítili ve vodě soběstační a samostatní.

Graf a tabulka 3: Výsledky pro klienty s kvadruparetickou formou DMO

\begin{tabular}{|c|c|c|c|c|c|c|c|c|c|c|c|c|c|}
\hline & $\begin{array}{c}\text { Akceptace } \\
\text { vodního } \\
\text { prostředí }\end{array}$ & $\begin{array}{l}\text { Vstup do } \\
\text { bazénu }\end{array}$ & $\begin{array}{l}\text { Výstup z } \\
\text { bazénu }\end{array}$ & $\begin{array}{l}\text { Dechová } \\
\text { kontrola }\end{array}$ & $\begin{array}{l}\text { Horizontá } \\
\text { Ini rotace }\end{array}$ & Splývání & $\begin{array}{l}\text { Strǐikání } \\
\text { vody }\end{array}$ & $\begin{array}{l}\text { Potápění } \\
\text { se/ponoř } \\
\text { ení se }\end{array}$ & $\begin{array}{l}\text { Udř̌ení } \\
\text { ve } \\
\text { vertikální } \\
\text { poloze }\end{array}$ & $\begin{array}{c}\text { Kvadrupe } \\
\text { dálni } \\
\text { lokomoce }\end{array}$ & $\begin{array}{l}\text { Stoj ve } \\
\text { vodẽ }\end{array}$ & $\begin{array}{l}\text { Drženíse } \\
\text { lana }\end{array}$ & $\begin{array}{l}\text { Sed ve } \\
\text { vodĕ, } \\
\text { pozice } \\
\text { żidle } \\
\end{array}$ \\
\hline $\begin{array}{c}\text { před } \\
\text { terapii } \\
\text { Halliwick } \\
\text { metodou }\end{array}$ & 3,3 & 1,0 & 1,0 & 2,0 & 2,3 & 3,3 & 3,0 & 1,5 & 2,0 & 1,5 & 1,0 & 1,3 & 2,0 \\
\hline $\begin{array}{l}\text { po terapií } \\
\text { Halliwick } \\
\text { metodou }\end{array}$ & 4,0 & 1,3 & 1,3 & 3,0 & 3,5 & 3,3 & 3,5 & 2,3 & 2,0 & 2,0 & 1,8 & 2,3 & 2,3 \\
\hline
\end{tabular}

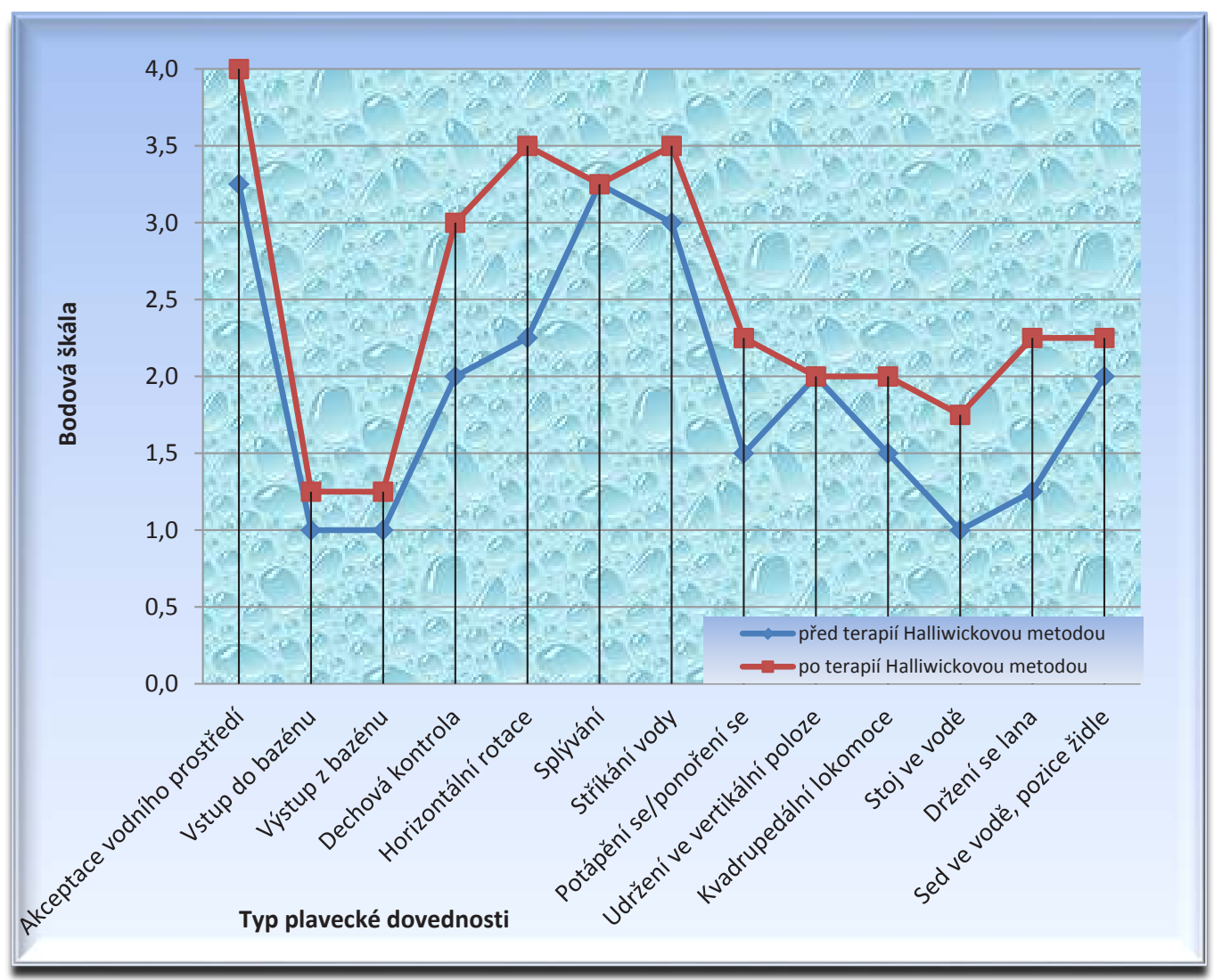


Třetí skupinu představují klienti s kvadruspastickou formou DMO, která prokázala zlepšení v bodovém hodnocení o 0,56 bodu - viz tabulka a graf č. 3 . Počet probandů $n=6$.

Jelikož je kvadruspastická forma DMO nejtěžší z těchto tří diagnóz, náš předpoklad, že u této skupiny klientů bude nejmenší pokrok v plaveckých dovednostech, byl správný. Reálně jsem neočekávala velké změny v plaveckých dovednostech ve smyslu naučit klienty samostatný plavecký způsob.

Přesto jsem i u této skupiny klientů zaznamenala zlepšení plaveckých dovedností v rozvoji kontroly dechu, splývání a ponoření se do vody. Samostatný pohyb pod vodní hladinou se objevil jen ojediněle.

Velký pokrok klienti ale udělali v nácviku rotací. Tento nácvik lze poté uplatnit na souši při fyzioterapii a opět při ADL v jejich každodenním životě.

Taktéž malé pokroky byly zaznamenány v nácviku kvadrupedální lokomoce ve vertikále a nácviku úchopu ve vertikále. Nacvičovat tuto motorickou kompetenci na souši by bylo téměř u všech klientů nereálné. Proto bylo opět velmi vhodné využít vodní prostředí pro nácvik bipedální lokomoce, aktivace propriocepce a zapojení horních končetin a úchopu při vertikální aktivitě.

Výzkumem jsme došli ke zjištění, že Halliwickův koncept je velmi vhodnou vodní terapií pro různé typy diagnóz DMO a autismu. U všech těchto typů diagnóz došlo ke zlepšení plaveckých dovedností. Zjistili jsme také, že test WOTA je velmi vhodnou měřící škálou pro zhodnocení změn plaveckých dovedností u klientů se specifickými potřebami.

\section{DISKUSE}

Getz a kol.(2006) popsali ve své studii velmi pozitivní vliv Halliwickova konceptu na rozvoj plaveckých dovedností u dětí s neurologickými diagnózami. Provedli rozsáhlé statistické šetření na 40 probandech (děti v rozmezí 3-7 let, převážně s diagnózou DMO). Prováděli 5měsíční intervenci s pretest a posttest designem s užitím hodnotící škály AIM (Aquatic Independence Measure). Tento test je velice podobný WOTA testu - hodnotí podobné plavecké dovednosti. Je rozsáhlejší, skládá se z 22 položek, se škálou 0-4 hodnocení dle míry soběstačnosti provedeného pohybu ve vodě. Po 5měsíční intervenci udává až $77 \%$ zlepšení plaveckých dovedností u těchto probandů.

I když tento kolektiv pracoval s mladšími dětmi a použivali jinou měřící škálu pro hodnocení plaveckých dovedností, lze sledovat určité paralely jejich a mých výsledků. Udávají, že $70 \%$ dětí vykazovalo zlepšení v kontrole dechu a $62 \%$ dětí zvládlo potápění hlavy pod hladinu. V našem případě došlo ke zlepšení v potápění hlavy u $67 \%$ klientů. Také bychom mohli najít obdobu u transferů. Getz a kol. uvádějí až 90\% zlepšení $\mathrm{u}$ transferů do a $\mathrm{z}$ vody. My jsme zaznamenali pokrok v této dovednosti u klientů s diparetickou formou a u klientů s autismem.

Existuje jistě celá řada jiných př́stupů vodní terapie a intervence, které budou stejně pozitivně ovlivňovat motorickou kompetenci ve vodním prostředí (např. Bb kontakt). Mě však zaujal Halliwickův koncept zejména pro svůj pedagogický postup při učení pohybové aktivity a pro jasnou, srozumitelnou strukturu. Také mě tento koncept oslovil individuálním př́istupem, individuálním tempem učení.

Taktéž bychom mohli diskutovat o vhodnosti zvolené hodnotící škály WOTA. Tento test mě velice zaujal tím, že kopíruje dovednosti, které se klient právě učí při Halliwickově konceptu. Jako by byl „šitý na míru“ právě k hodnocení tohoto konceptu. Je také jasně strukturovaný a bodové hodnocení je zřetelně odděleno, bere v potaz pohyb celého člověka, nejen jedné části. Autoři testu také pracují na jeho další, rozšířené formě, aby zachytili co nejvíce nuancí v rozvoji plaveckých dovedností.

V neposlední řadě bychom mohli diskutovat o vhodně zvolené interpretaci výsledků měření. Jelikož již 6 let pracuji s těmito klienty jako fyzioterapeutka, jsem zastáncem př́ípadového šetření a vím, že každý jedinec je originál a průměrné hodnoty nevypovídají nic o individuální snaze každého jedince. Takové výsledky by byly opravdu velmi zdlouhavé. Rozhodla jsem se výsledky rozdělit alespoň dle typu diagnóz na tři skupiny, abych mohla doložit grafické znázornění plaveckých úspěchů klientů.

\section{ZÁVĚRY}

Výzkumem bych chtěla dokázat, že Halliwickův koncept přináší klientům rozvoj jejich motorické kompetence a rozvoj plaveckých dovedností. Mimo jiné jim pohyb ve vodním prostředí přináší benefity jako ovlivnění spasticity (při vhodné teplotě vody), zlepšení funkční síly a mobility, ovlivnění subjektivních potíží, 
zlepšení proprioceptivních vstupů, zlepšení psychického rozpoložení. Přínos však není v tomto příspěvku dokázán. Ráda bych našla vhodné hodnotící škály, které by tyto benefity pro klienty dokázaly. Co je však zcela jisté a nevyvratitelné je, že klienti byli obohaceni o novou pohybovou aktivitu, která jim zkvalitní život.

\section{LITERATURA}

Association of swimming therapy. (1992) Swimming for people with disabilities. London, England: A \& C Black

Getz, M., Hutzler, Y., \& Vermeer, A. (2006). The Relationship Between Aquatic Independence and Gross Motor Function in Children with Neuro-Motor Impairments. Adapted physical activity quarterly. 339-355.

Grosse, S. J. (2010). Water freedom for all: the Halliwick method. International Journal of Aquatic Research and Education, 4. 199-207.

Harris, R. \& Dendy, E. (1992). Swimming for people with disabilities, London, England: A \& C Black

Kepštová, L. (2011). Halliwickưv koncept výuky plavání. Bakalářská práce. Olomouc: Univerzita Palackého v Olomouci

Pacholík, V. (2010). Ve vodě s úsměvem. Aplikované pohybové aktivity v teorii a praxi II (1), 20-26 Olomouc: Univerzita Palackého v Olomouci.

Pacholík, V., Vlčková, I. \& Blahutková, M. (2009). Halliwickova metoda plavání. Brno: Masarykova univerzita. Saulová, J. (2007) Popis metodologie Halliwickovy metody plavání. Bakalářská práce. Brno: Masarykova univerzita.

Šarinová, M. \& Čechovská, I. (2005) Plavecká poloha u dětí s diagnózou dětská mozková obrna. Role pohybových aktivit v životě dětí a mládeže. Praha: Falon.

Tirosh, R., Katz-Leurer, M. \& Getz, M. D. (2008). Halliwick-based aquatic assessments: reliability and validity. International Journal of Aquatic Research and Education, 2. 224-236.

Válková, H., (2010). Kudy na to? O motorické kompetenci a principech adaptace v APA. Aplikované pohybové aktivity v teorii a praxi I (2), 31- 39. 